\title{
Linking crop and livestock diversification to household nutrition: Evidence from Guruve and Mt Darwin districts, Zimbabwe
}

\author{
Conrad Murendo $^{\mathrm{a}, *}$, Simon Gwara ${ }^{\mathrm{a}}$, Kizito Mazvimavi ${ }^{\mathrm{a}}$, Jeffrey Scott Arensen ${ }^{\mathrm{b}}$ \\ ${ }^{a}$ International Crops Research Institute for the Semi-Arid Tropics, P. O. Box 776, Bulawayo, Zimbabwe \\ ${ }^{\mathrm{b}}$ World Vision, P. O. Box 2420, Mt Pleasant, Harare, Zimbabwe
}

\section{A R T I C L E I N F O}

\section{Keywords:}

Crop and livestock diversity

Dietary diversity

Food consumption

\begin{abstract}
A B S T R A C T
This study analyzed the role of crop and livestock production diversification on household nutrition in Zimbabwe using data from 986 households in Guruve and Mt Darwin districts. Data were analyzed using poisson and negative binomial regression, which showed that livestock and crop diversification were positively associated with household dietary diversity and food consumption. Pulse production was associated with a significant increase in dietary diversity and food consumption in both districts. Cattle production was significant and positively correlated with food consumption in the two districts. Goat and poultry rearing were significant and positively correlated with dietary diversity and food consumption in Mt Darwin. Promoting crop and livestock diversification is crucial for improved nutrition among smallholder farmers. In particular, investments in cereals, roots and tubers and pulse production together with cattle and small livestock such as poultry and goats are viable interventions for the improvement of household nutrition among smallholder farmers. A diversification strategy, which integrates crop and livestock production needs to be promoted.
\end{abstract}

\section{Introduction}

Agriculture interventions can improve nutrition among smallholder farmers in developing countries (Ruel \& Alderman, 2013). Nutrition is closely linked to agriculture, primarily because agriculture is the sector that produces food, and many of the undernourished population in the world are smallholder farmers. Agriculture may influence nutrition of households through production of food crops or animals which affect food available for household consumption, sale of agricultural goods that affect household incomes and therefore food purchases and consumption; and women's empowerment, which affects income and nutrition (Jones, Shrinivas, \& Bezner-Kerr, 2014).

In Zimbabwe, World Vision, Mercy Corps, Farmers Association of Community Self-Help Investment Group and International Crops Research Institute for Semi-Arid Tropics are implementing the Ensuring Nutrition, Transforming and Empowering Rural Farmers and Promoting Resilience in Zimbabwe (ENTERPRIZE) project. The project is working with diverse stakeholders to improve the food and nutrition security of at least 25,500 small holder farmers in 45 wards in Mt. Darwin and Guruve districts which are located in Mashonaland Central province in Zimbabwe. Some of the project components include: promotion of crop and livestock diversification, climate smart agriculture practices, linking farmers to markets, nutrition education promoting consumption of diverse nutritious foods.

There is a growing body of literature analyzing the links between crop and livestock diversification on nutrition with findings generally indicating a positive relationship. However, there is only anecdotal evidence on the effects of crop and livestock production diversification on household dietary diversity and food consumption among households in developing countries. Using, a case study of ENTERPRIZE project, the paper examines the role of crop and livestock diversification on nutrition. Data were collected from 330 and 657 households in Guruve and Mt Darwin districts respectively. Unlike previous studies, this article disaggregates and analyze separately the different crop and livestock production practices to understand their association with household nutrition. Understanding this relationship is relevant policy and development intervention especially for smallholder farmers that rely solely on crop farming. Furthermore, we use two nutritional outcomes - household dietary diversity (HDDS) and food consumption score (FCS) unlike previous studies which focus solely on one nutritional outcome. Dietary diversity is increasingly being used as an indicator of dietary quality while food consumption score reflects the quality and quantity of food access at the household level (Leroy, Ruel, Frongillo, Harris, \& Ballard, 2015).

\footnotetext{
* Corresponding author.

E-mail addresses: cmurendo@hotmail.com, c.murendo@cgiar.org (C. Murendo).
} 


\section{Case study demographics}

Results on crop diversity show that households in Mt Darwin cultivated more crop species than in Guruve. Households in Guruve rear more livestock species compared to Mt Darwin. In terms of age, household heads in Guruve are 2 years older than their counterparts in Mt Darwin with the average age of 47 years. Using the geographic distance from the farm household to the closest market where food can be sold to indicate market access, households in Mt Darwin are located further away from market compared to Guruve. This means that farmers in Mt Darwin incur higher travel costs to the market and this can potentially lower the budget available for purchase of diverse and nutritious foods from the market. Households facing such constraints may be considered autarkic and may only consume what they produce due to high transaction costs. Off-farm income increase the households' ability to buy diverse foods from the market and consequently increases dietary diversity. Households in Guruve has more members engaged in off-farm income activities than those in Mt Darwin.

\section{Food group consumption and household dietary diversity}

Food groups that were consumed the most included (Table 1): cereals (94.4\%), vegetables (90.4\%), oils/fats (90\%), condiments/ spices/beverages (80.9\%), and sugar and sweets (78.9\%). Animal-based foods such as meats $(21.8 \%)$ and poultry and eggs $(20.0 \%)$ were the least consumed. Among households who had consumed foods from the given food groups, households' own production was the main source of vegetables $(81.4 \%)$, nuts and pulses $(76.2 \%)$ and cereals $(75.0 \%)$ whereas, oils and fats, sugars and sweets, condiments and spices, fish and milk products were mainly acquired through purchasing. About $27 \%$ and $14 \%$ of the households were categorized as having low diversity in Mt Darwin and Guruve respectively. Guruve had higher proportion of households who had higher dietary diversity which can be attributed to lower travel costs and higher crop-livestock integration.

\section{Crop and livestock diversity and household nutrition}

Results in Table 2 show that crop diversity positively increases household dietary diversity and food consumption. An additional crop

\section{Table 1}

Proportion of households which had consumed foods from each food group and main sources of these food consumed.

\begin{tabular}{|c|c|c|c|c|c|c|c|c|}
\hline \multirow[t]{3}{*}{ Food group } & \multirow{2}{*}{\multicolumn{2}{|c|}{$\begin{array}{l}\text { Consumption } \\
(n=987)\end{array}$}} & \multicolumn{6}{|c|}{ Main source } \\
\hline & & & \multicolumn{2}{|c|}{ Own production } & \multicolumn{2}{|c|}{ Purchased } & \multicolumn{2}{|c|}{ Other } \\
\hline & $\mathrm{N}$ & $\%$ & $\mathrm{~N}$ & $\%$ & $\mathrm{n}$ & $\%$ & $\mathrm{n}$ & $\%$ \\
\hline Cereals & 932 & 94.4 & 699 & 75 & 171 & 18.3 & 62 & 6.7 \\
\hline $\begin{array}{r}\text { Roots and } \\
\text { tubers }\end{array}$ & 447 & 45.3 & 261 & 58.4 & 135 & 30.2 & 51 & 11.4 \\
\hline $\begin{array}{l}\text { Nuts and } \\
\text { pulses }\end{array}$ & 730 & 74 & 556 & 76.2 & 96 & 13.2 & 78 & 10.6 \\
\hline Vegetables & 892 & 90.4 & 726 & 81.4 & 133 & 14.9 & 33 & 3.7 \\
\hline Fruits & 428 & 43.4 & 272 & 63.6 & 79 & 18.5 & 77 & 17.9 \\
\hline Meats & 215 & 21.8 & 59 & 22.4 & 18 & 8.4 & 138 & 64.2 \\
\hline $\begin{array}{l}\text { Poultry and } \\
\text { eggs }\end{array}$ & 197 & 20 & 126 & 64 & 58 & 29.4 & 13 & 6.6 \\
\hline $\begin{array}{l}\text { Fish and } \\
\text { shellfish }\end{array}$ & 238 & 24.1 & 31 & 13 & 157 & 66 & 50 & 21 \\
\hline $\begin{array}{c}\text { Milk and dairy } \\
\text { products }\end{array}$ & 257 & 26 & 84 & 32.7 & 156 & 60.7 & 17 & 6.6 \\
\hline $\begin{array}{l}\text { Sugar and } \\
\text { sweets }\end{array}$ & 779 & 78.9 & 28 & 3.6 & 708 & 90.9 & 43 & 5.5 \\
\hline Oils and fats & 888 & 90 & 38 & 4.3 & 811 & 91.3 & 39 & 4.4 \\
\hline $\begin{array}{l}\text { Condiments, } \\
\text { spices \& } \\
\text { beverages }\end{array}$ & 798 & 80.9 & 40 & 5 & 713 & 89.4 & 45 & 5.6 \\
\hline
\end{tabular}

species increases dietary diversity by $7.9 \%$ and $4.4 \%$ in Guruve and Mt Darwin respectively. In Mt Darwin district, an additional livestock specie increases dietary diversity by $6.1 \%$. In addition, our results show that livestock diversity increases food consumption score in both districts. Promoting development interventions that encourage crop-livestock diversification in smallholder farming communities is not only an important risk and climate change mitigation strategy but also as a nutrition enhancing strategy.

\section{Role of market access, off-farm income and nutrition training}

Households in remoter regions of these districts have lower dietary diversity. An additional kilometer away from the farm household reduced dietary diversity by $0.2 \%$ and $0.1 \%$ in Guruve and Mt Darwin respectively. Furthermore, an additional kilometer away from the homestead reduces food consumption in Guruve. Facilitating better market access and networks within the two districts through reduced distances could therefore contribute to higher dietary diversity among smallholder farmers. The results also show that off-farm income has a positive and significant association with dietary diversity and food consumption for Mt Darwin only. Having an additional member engaged in off-farm income activity increases dietary diversity by $2.7 \%$ in $\mathrm{Mt}$ Darwin. These results are in line with previous studies highlighting the importance of income diversification on dietary diversity (Romeo, Meerman, Demeke, Scognamillo, \& Asfaw, 2016). Policy intervention to increase household dietary diversity should emphasize on promoting both farm diversification and off-farm income diversification. Nutrition training was also found to increase dietary diversity by $8 \%$ in Guruve. Education programmes that focus on training smallholder farmers on the importance of nutrition, crop and livestock diversification are crucial.

\section{Association between individual agricultural practices and household nutrition}

Our results indicated that the cultivation of cereals was associated with a significant increase in food consumption score in Guruve while roots and tubers had significant relationship with FCS in both districts (Table 3). The cultivation of beans and pulses was associated with a significant increase in dietary diversity and food consumption in both districts. For example, the cultivation of beans and pulses increase dietary diversity by $12 \%$ and $11.8 \%$ in Guruve and Mt Darwin districts respectively. Cattle ownership was significantly and positively correlated with food consumption in the two districts. Goat and poultry production increased dietary diversity by $9.6 \%$ and $7 \%$ respectively in Mt Darwin. The majority of farmers practice a mix of subsistence and market-oriented production and these associations could be through availability of foods due to production-for-own-consumption, or to income effects resulting from the sale of surplus agricultural products (Jones et al., 2014; Romeo et al., 2016).

\section{Conclusion and policy implications}

The study results show that crop and livestock diversity had a strong and positive association with household dietary diversity and food consumption. Households that diversified their farm activities improved their dietary diversity in both districts. Growing of beans and pulses was associated with a significant increase in dietary diversity and food consumption in both districts. Cattle ownership was significant and positively correlated with food consumption in the two districts. Goat and poultry rearing were significant and positively correlated with dietary diversity and food consumption in Mt Darwin only. These results suggest that interventions that increase small stock production in Mt Darwin are beneficial for household nutrition.

From a policy perspective, results suggest that the promotion of crop and livestock diversification is crucial for improved nutrition among smallholder farmers. One possible intervention is offering education to 
Table 2

Crop and livestock diversity on household nutrition.

\begin{tabular}{|c|c|c|c|c|c|c|}
\hline & \multicolumn{3}{|c|}{ Dietary diversity } & \multicolumn{3}{|c|}{ Food consumption score } \\
\hline & Pooled & Guruve & Mt Darwin & Pooled & Guruve & Mt Darwin \\
\hline Crop diversity & $\begin{array}{l}0.053^{\text {ktkkt }} \\
(0.012)\end{array}$ & $\begin{array}{l}0.079^{k * k * k} \\
(0.023)\end{array}$ & $\begin{array}{l}0.044^{\text {*k/k }} \\
(0.013)\end{array}$ & $\begin{array}{l}0.075^{k * k *} \\
(0.012)\end{array}$ & $\begin{array}{l}0.078^{\text {kx/k }} \\
(0.024)\end{array}$ & $\begin{array}{l}0.077^{\text {kek*k }} \\
(0.014)\end{array}$ \\
\hline Livestock diversity & $\begin{array}{l}0.054^{\text {k*k:k}} \\
(0.012)\end{array}$ & $\begin{array}{l}0.025 \\
(0.023)\end{array}$ & $\begin{array}{l}0.061^{\text {*n*k }} \\
(0.014)\end{array}$ & $\begin{array}{l}0.079^{k \ldots * k} \\
(0.013)\end{array}$ & $\begin{array}{l}0.091^{\text {**kik }} \\
(0.025)\end{array}$ & $\begin{array}{l}0.071^{* \ldots * k} \\
(0.015)\end{array}$ \\
\hline Market distance & $\begin{array}{l}-0.001^{* * * *} \\
(0.000)\end{array}$ & $\begin{array}{l}-0.002^{* *} \\
(0.001)\end{array}$ & $\begin{array}{l}-0.001^{*} \\
(0.000)\end{array}$ & $\begin{array}{l}-0.001^{*} \\
(0.000)\end{array}$ & $\begin{array}{l}-0.003^{\text {***k }} \\
(0.001)\end{array}$ & $\begin{array}{l}-0.000 \\
(0.000)\end{array}$ \\
\hline Off-farm income & $\begin{array}{l}0.017^{\text {k.kkk }} \\
(0.006)\end{array}$ & $\begin{array}{l}0.007 \\
(0.010)\end{array}$ & $\begin{array}{l}0.027^{\text {*kxk}} \\
(0.010)\end{array}$ & $\begin{array}{l}0.013^{*} \\
(0.007)\end{array}$ & $\begin{array}{l}0.012 \\
(0.011)\end{array}$ & $\begin{array}{l}0.025^{\text {*ke }} \\
(0.010)\end{array}$ \\
\hline Nutrition training & $\begin{array}{l}0.004 \\
(0.025)\end{array}$ & $\begin{array}{l}0.079^{k} \\
(0.042)\end{array}$ & $\begin{array}{l}-0.036 \\
(0.031)\end{array}$ & $\begin{array}{l}-0.009 \\
(0.026)\end{array}$ & $\begin{array}{l}0.008 \\
(0.044)\end{array}$ & $\begin{array}{l}-0.008 \\
(0.033)\end{array}$ \\
\hline $\begin{array}{l}\text { Other covariates } \\
\text { Constant }\end{array}$ & $\begin{array}{l}\text { Yes } \\
1.742^{* * * *} \\
(0.070)\end{array}$ & $\begin{array}{l}\text { Yes } \\
1.981^{\text {k**k}} \\
(0.121)\end{array}$ & $\begin{array}{l}\text { Yes } \\
1.701^{* * * *} \\
(0.087)\end{array}$ & $\begin{array}{l}\text { Yes } \\
3.198^{* k *} \\
(0.073)\end{array}$ & $\begin{array}{l}\text { Yes } \\
3.395^{* * * k} \\
(0.127)\end{array}$ & $\begin{array}{l}\text { Yes } \\
3.124^{* * * * *} \\
(0.088)\end{array}$ \\
\hline $\begin{array}{l}\text { No. of observations } \\
\text { Alpha }\end{array}$ & 975 & 329 & 646 & $\begin{array}{l}975 \\
-2.033^{\text {k*k* }} \\
(0.055)\end{array}$ & $\begin{array}{l}329 \\
-2.146^{\text {***k }} \\
(0.098)\end{array}$ & $\begin{array}{l}646 \\
-2.034^{\text {**** }} \\
(0.068)\end{array}$ \\
\hline
\end{tabular}

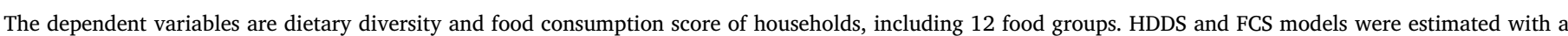

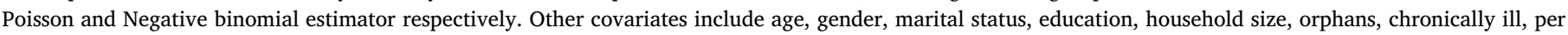

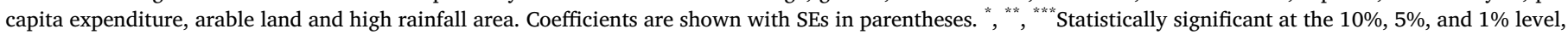
respectively.

Table 3

Regression analysis of individual crop and livestock production practices on household nutrition.

\begin{tabular}{|c|c|c|c|c|c|c|}
\hline & \multicolumn{3}{|c|}{ Dietary diversity } & \multicolumn{3}{|c|}{ Food consumption score } \\
\hline & Pooled & Guruve & Mt Darwin & Pooled & Guruve & Mt Darwin \\
\hline \multirow[t]{2}{*}{ Cereals } & 0.176 & 0.158 & 0.132 & $0.284^{* * *}$ & $0.475^{* * *}$ & 0.090 \\
\hline & $(0.130)$ & $(0.177)$ & $(0.196)$ & $(0.127)$ & $(0.168)$ & $(0.185)$ \\
\hline \multirow[t]{2}{*}{ Roots and tubers } & 0.024 & -0.001 & 0.076 & $0.108^{\text {k.k.k }}$ & $0.097^{* k *}$ & $0.165^{\text {k*k:k }}$ \\
\hline & $(0.032)$ & $(0.045)$ & $(0.048)$ & $(0.035)$ & $(0.046)$ & $(0.052)$ \\
\hline \multirow[t]{2}{*}{ Beans and pulses } & $0.112^{\text {k*kk }}$ & $0.120^{\text {k**** }}$ & $0.118^{* * * *}$ & $0.092^{\text {***k* }}$ & $0.095^{* * *}$ & $0.113^{\text {k.k.k }}$ \\
\hline & $(0.025)$ & $(0.043)$ & $(0.032)$ & $(0.027)$ & $(0.044)$ & $(0.033)$ \\
\hline \multirow[t]{2}{*}{ Vegetables and fruits } & -0.009 & 0.065 & -0.018 & $-0.076^{*}$ & 0.028 & $-0.096^{\text {k*k }}$ \\
\hline & $(0.039)$ & $(0.086)$ & $(0.044)$ & $(0.041)$ & $(0.090)$ & $(0.047)$ \\
\hline \multirow[t]{2}{*}{ Cattle } & $0.054^{*}$ & 0.072 & 0.042 & $0.122^{\text {*kxke }}$ & $0.192^{* k * k}$ & $0.098^{* * k * k}$ \\
\hline & $(0.028)$ & $(0.051)$ & $(0.035)$ & $(0.030)$ & $(0.051)$ & $(0.036)$ \\
\hline \multirow[t]{2}{*}{ Goats } & $0.065^{* * k}$ & 0.003 & $0.096^{\text {***k }}$ & $0.106^{\text {****k }}$ & 0.070 & $0.114^{\text {k*k*k}}$ \\
\hline & $(0.026)$ & $(0.046)$ & $(0.032)$ & $(0.027)$ & $(0.047)$ & $(0.033)$ \\
\hline \multirow[t]{2}{*}{ Poultry } & $0.064^{* * x}$ & 0.044 & $0.070^{*}$ & 0.046 & 0.005 & $0.075^{\text {kik }}$ \\
\hline & 0.176 & 0.158 & 0.132 & $(0.031)$ & $(0.059)$ & $(0.037)$ \\
\hline \multirow[t]{2}{*}{ Constant } & $1.630^{\text {*kxke }}$ & $1.935^{* * * *}$ & $1.613^{\text {***** }}$ & $3.075^{\text {*x/ke }}$ & $3.139^{\text {k*k* }}$ & $3.171^{* * * * k}$ \\
\hline & $(0.144)$ & $(0.206)$ & $(0.211)$ & $(0.142)$ & $(0.198)$ & $(0.201)$ \\
\hline \multirow{3}{*}{$\begin{array}{l}\text { No. or ODservations } \\
\text { Alpha }\end{array}$} & 975 & 329 & 646 & 975 & 329 & 646 \\
\hline & & & & $-2.034^{\text {*nkk }}$ & $-2.192^{* * * *}$ & $-2.047^{\text {k*k*k}}$ \\
\hline & & & & $(0.055)$ & $(0.099)$ & $(0.068)$ \\
\hline
\end{tabular}

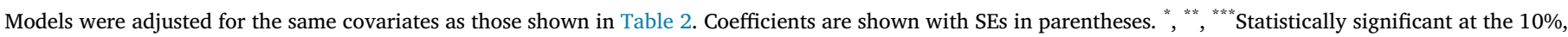
$5 \%$, and $1 \%$ level, respectively.

farmers on the importance of nutrition, crop and livestock diversification. Such farmer trainings should focus on suitable types of crops to grow and what combinations of crops to grow to improve household food security and nutrition. Overall, to improve household nutrition, extension should promote interventions that enhance crop, livestock and off-farm diversification. These interventions should be complemented by market integration and nutrition education.

\section{Conflict of interest}

None.

\section{Acknowledgments}

We acknowledge World Vision Zimbabwe for sharing data. The authors gratefully acknowledge UK, Department for International Development and Food and Agriculture Organization of the United Nations for funding the ENTERPRIZE project. The views expressed in this article are those of the authors and do not necessarily reflect the views or policies of these institutions, while errors are solely responsibility of the authors. 


\section{Appendix A. Supplementary data}

Supplementary data to this article can be found online at https:// doi.org/10.1016/j.wdp.2019.02.015.

\section{References}

Jones, A. D., Shrinivas, A., \& Bezner-Kerr, R. (2014). Farm production diversity is associated with greater household dietary diversity in Malawi: Findings from nationally representative data. Food Policy, 46, 1-12.
Leroy, J. L., Ruel, M., Frongillo, E. A., Harris, J., \& Ballard, T. J. (2015). Measuring the food access dimension of food security: A critical review and mapping of indicators. Food and Nutrition Bulletin, 36, 167-195.

Romeo, A., Meerman, J., Demeke, M., Scognamillo, A., \& Asfaw, S. (2016). Linking farm diversification to household diet diversification: Evidence from a sample of Kenyan ultra-poor farmers. Food Security, 8, 1069-1085.

Ruel, M. T., \& Alderman, H. (2013). Nutrition-sensitive interventions and programmes: How can they help to accelerate progress in improving maternal and child nutrition? The Lancet, 382, 536-551. 